\title{
Gróf Esterházy Károly egri püspök magánuradalmának Főtemploma, a pápai Nagytemplom (belső architektúra) (DVD-melléklet)
}

Gróf Esterházy Károly római tanulmányai befejezése után 1748-ban tért haza szülei rezidenciájába, Pápára. Egyházi szolgálatát is a városban kezdte, két évig volt káplán. Misézett, gyóntatott, betegeket látogatott, ismerkedett az egyház szolgáinak mindennapjaival.

Később, mint földesúr a középkori város piacteréből kialakíttatta a mai barokkos hangulatú Fő teret. Lecsapoltatta az egykori várat és várost körülölelő mocsaras tavat. Itt jött létre a Várkert, később egy új városrész is.

A földesúr-püspök főműve városunkban a monumentális Nagytemplom. A filmen és az előadásban ennek belső tereivel ismerkedhetünk meg.

A templom külső és belső méretei érzékeltetik Esterházy Károly földesúri gazdagságát és egyházföi vallásos elkötelezettségét magánuradalmi központja, Pápa iránt.

Az egybefüggő belső teret a hajó boltozatai a diadalív és a szentély tagolja. A hajóban lévő pillérekkel íves fülkékbe került a négy mellékoltár. A lábazatból indulnak a pillérek, záródásukban aranyozott, díszes oszlopfókkel, amelynek motívumai megismétlik a torony oszlopai külső fejezeteit. Ezeken nyugszik a jól tagolt, a belsőteret körbefutó párkány rendszer.

A mennyezet freskóit egyetlen nézőpontra komponálták, a belépő hívő ember nézőpontjára. Mindenben érvényesült a megrendelő akarata. Maulbertsch többször átalakította terveit, amelyek híven követik a római Santo Stefano Rotondo templom kompozíciói. (Esterházy Károlyt egykor ebben a templomban szentelték pappá.)

A kupola freskók: Szent István és társai diakónussá szentelése. Majd a prédikáló szent, a későbbi vértanú jelenik meg a másodikban. A szentélyben lévő kupola freskón elfogják. Végül sorsa Huber Maurer hatalmas oltárképén teljesedik be: megkövezik.

Maulbertsch szignója az első kép bal alsó oldalán látható. Anton 'A' szigláját egy gyönyörü vadrózsa ág választja el a tulajdonnév teljes alakjától.

A fooltár tabernákulumának a háza monumentális uráli malachitból készült. Gyönyörű bronz ajtaján Ábrahám és Izsák jelenete látható. A főoltár alkotója 
Grossmann József építész, aki a templomot tervező Fellner Jakab halála után vezette az építkezést.

A fóoltár melletti oszlopcsarnokban Szent László és Szent István királyaink életnagyságú alakjai uralják a teret. Carrarai márványból készültek, a többi oltáron lévő szobrászati alkotással együtt, Philip Prokop alkotásai.

A mellékoltárokat: Szent Annának Szűz Mária édesanyjának, Szent Józsefnek Krisztus nevelőapjának, Boromeo Szent Károlynak, - ezen a képen megjelenik a donátor Esterházy alakja, mint első szerpap - végül az utolsót Nepomuki Szent Jánosnak, a gyónási titok vértanújának szentelték.

A szószék, a padok és a gyóntatószékek művészi faragásúak, horvátországi tölgyfából készültek. Mindezek jól illeszkednek a templom visszafogott klasszicizáló belső világához.

A keresztút domborműveit a pápai származású festőművész Cziráki Lajos készítette.

A templom történetének jeles eseményeit, személyiségeit emléktáblákkal örökíti meg az utókor. (A felszentelés, ennek a 200 éves évfordulója, a tervező és a festő, a pápai Nagytemplomban szolgált plébánosok névsora.) A missziós kereszten a Veszprém megyei születésű Kopácsi József veszprémi püspök, később bíboros hercegérsek emléktáblája látható, melyet a kései leszármazott rokonok állítottak. Ő volt a Széchenyi kezdeményezte Magyar Tudós Társaság első főpapi támogatója. Egyházmegyéiben elrendelte a magyar nyelv hivatali használatát.

A templomhoz a fö tömegén kívül, oldalkápolnaszerű megoldással sekrestye és Szűz Mária tiszteletére szentelt kápolna és mindkettő emeletén oratórium csatlakozik.

A Szűz Mária kápolnában és az oratóriumban egyházművészeti kiállítás látható.

Az oltár menzájában üvegkoporsóban, található Szent Martialis vértanú, magyaros ruhába öltöztetett vázereklyéje.

Jelenleg itt látható a barokk keresztelő medence is, amelynek Jézus megkeresztelkedik a Jordán folyóban c. szoborkompozíciója szintén Prokop alkotása. Sajnos az eredetit a kilencrenes évek elején ellopták, a jelenlegi alkotást Marton László készítette, az eredetivel mindenben megegyezően.

Kérem, nézzék meg a filmet és látogassák meg a pápai Nagytemplomot! Jöjjenek el hozzánk! Pápa városképe Egerhez hasonlóan a magyarországi barokk építkezés egyik szép példája. 


\section{The Main Church on the Private Estate of Count Károly Esterházy, Bishop of Eger: the Great Church of Pápa (interior architecture)}

In 1748 Count Károly Esterházy returned home to Pápa after his studies in Paris. He started his parochial services in the town. He was a chaplain for two years during which he familiarised himself with the everyday routine of the servants of the church.

Later as a squire, he had the the medieval town's marketplace refurbished into today's Baroque-style main square. As part of this development, he had the ancient swamp surrounding the castle and the town drained.

The masterpiece of the lord-bishop is, however, the main church. The DVDdocumentary and the paper aims to introduce its interior spaces.

The inside and outside measurements of the church showcase Károly Esterházy's wealth as a squire, as well as his religious commitment to the centre of his private estate, Pápa.

The contiguous interior of the church is divided by the nave's vaults, the arch and the temple. The four side altars are set into the arched niches with pillars in the nave.

The frescos on the ceiling were composed to only one point of view, that of the believer who enters the church. The frescos are as follows: The consecration of Saint Stephen and his companions to deacons. The preaching saint appears in red, white and green hemmed cloak in the second one. On the fresco in the sanctuary he is taken captive. Finally, his fate of being stoned is depicted on Mauer's huge altarpiece.

The monumental house of the tabernacle is made of Ural malachite. On its door the story of Abraham and Isaac can be seen.

Next to the main altar, two of our kings, Saint László and Saint István, dominate the space. The statues were made of Carrara marble by Philip Prokop.

In the side altars there are paintings of Saint Anne, mother of Saint Mary; Saint Joseph, Jesus' adoptive father; Saint Charles Borromeo; and Saint John of Nepomuk.

The pulpit, the pews and the confessionals are artistically engraved. The reliefs of the Way of the Cross are made by a painter, who was born in Pápa, Lajos Cziráki.

There are remembrance plaques of the milestones of the Church's history and its significant persons.

The main body of the church connects a sacristy and a side chapel to Saint Mary, each with an oratory upstairs.

In the Saint Mary chapel and its oratory there is a religious art exhibition. In the mensa of the altar the body relic of Saint Martialis can be seen in a glass coffin.

The chapel also boasts of a Baroque baptismal font which was made by Prokop. 
Please come and visit us and the Main Church of Pápa. The cityscape of Pápa, similarly to Eger, is a beautiful example of Baroque architecture.

\section{Parochiálny kostol v Pápe - hlavný kostol súkromných majetk- ov Karola Eszterházyho (vnútorná architektúra) (príloha na DVD)}

Gróf Karol Eszterházy sa vrátil do pápskej rezidencie svojich rodičov po ukončení svojich štúdiív Ríme v roku 1748. Zároveň tu začal aj slúžiti. Neskôr, už ako zemepán, nechal pôvodné stredoveké trhovisko prebudovat na dnes známe barokové Hlavné námestie, kde nechal postavit monumentálny kostol. Prostredníctvom prednášky i dokumentu na DVD-nosiči sa zoznámime s interiérom tohto kostola.

Vonkajšie a vnútorné rozmery kostola nám pripomínajú nesmierne zemepanské bohatstvo Karola Eszterházyho ako aj jeho oddanost́ vo vztahu k centru svojich majetkov, Pápe. Súvislý celok interiéru je členený na menšie celky kostolnými klenbami, vítazným oblúkom a svätyňou. Vdaka pilierom kostolnej veže sa štyri bočné oltáre ocitli v oblúkovitých výklenkoch. Piliere sa uzatvárajú pozlátenými, bohato zdobenými hlavami, motívy ktorých opakujú vonkajšie motívy vežových stĺpov. Nad nimi dokola sa tiahne členená rímsa.

Stropné fresky sú komponované z pohl’adu jedného zorného uhlu: z pohl’adu veriaceho vstupujúceho do interiéru. Vo všetkom sa pritom zohladnil úmysel objednávatel'a prác. Maulbertsch aj viackrát prepracoval svoje plány, ktoré inak verne nasledujú kompozície vzorového kostola Santo Stephano Rotondo v Ríme. V kupole sú znázornené tematiky programu fresiek: Sv. Štefan sa stáva diakonom. Druhá freska zobrazuje neskoršieho svätca počas kázne, ktorý na freske kupoly svätyne padne do zajatia. Na záver sa jeho osud naplní na obrovskom plátne obrazu hlavného oltára: je ukameňovaný.

Maubertschovo signo je viditel'né v dolnom l’avom rohu prvého výjavu, pričom prvé písmeno jeho krstného mena „A“ je od ostatnej časti oddelené krásnou stonkou ruže. Tabernákulum hlavného oltára bolo vyrobené z monumentálneho uralského malachitu. Na prekrásnych bronzových dvierkach je výjav Abraháma a Izáka. Hlavný oltár je dielom Jozefa Grossmana, ktorý vedenie stavby prevzal po smrti Jakuba Fellnera.

StÍporadiu vedla hlavného oltára vládnu v životnej vellkosti vyhotovené sochy svätých králov: Štefana a Ladislava. Vyhotovené boli z carrarského mramoru a spolu s ostatnými sochami oltárov sú dielom Prokopa Philipa. 
Bočné oltáre boli zasvätené sv. Anne, matke Panny Márie, sv. Jozefovi, sv. Karolovi Boromejskému a posledný sv. Jánovi Nepomuckému, mučeníkovi spovedného tajomstva.

Kazatel'nica, lavice a spovednice sú bohato vyrezávané. Vyrobené sú z chorvátskeho dubu. Všetky zapadajú do príjemne klasicizujúcej vnútornej atmosféry kostola.

Významné udalosti histórie kostola a výročia ním súvisiacich osobností si pripomenuli d’alšie generácie viacerými pamätnými tabulami. Misijný kríž nesie pamätnú tabulu vesprémskeho biskupa, neskôr kardinála a primasa, miestneho rodáka Józsefa Veszpémiho, ktorú tu odhalili neskorí rodinní potomkovia. On bol prvým vysokopostaveným cirkevným hodnostárom, podporujúcim snahy Uhorského vedeckého spolku (Magyar Tudós Társaság) založeného na popud Széchenyho. V diecézach patriacich pod jeho správu zaviedol používanie mad’arčiny ako úradného jazyka.

Ku kostolu je spôsobom akoby bočnej kaplnky prilepená sakristia a Kaplnka Panny Márie. Na poschodí oboch sa spája oratórium

Na oltárnej menze sú v sklenenej truhle uložené relikvie sv. Martialisa, odeté na uhorský spôsob.

Momentálne je tu umiestnená verná kópia barokovej krstitel'nice, dalšieho Prokopovho diela, so sochársky stvárneným výjavom pokrstenia Ježiša v rieke Jordán. Žial' originál krstitel'nice bol ukradnutý začiatkom 90. rokov minulého storočia. Vernú kópiu vyhotovil László Marton. Prosím, pozrite si priložený dokumentárny film a prídte kostol i mesto Pápa navštívit!! Podobne mestu Eger, aj Pápa je jedným z pekných príkladov domáceho barokového stavitel'stva. 